\title{
Trace elements and antioxidant status in human immunodeficiency virus positive patients
}

\author{
Brahmareddy Malapati ${ }^{1}$, Shaikh Mohammed Nadeem ${ }^{1}$, Ivvala Anand Shaker ${ }^{2}$, and Bhavita Patel ${ }^{3, *}$ \\ ${ }^{1}$ Department of Biochemistry, Dr. Kiran C Patel Medical College, Bharuch, Gujarat-392001, India \\ ${ }^{2}$ Department of Biochemistry, Parul Institute of Medical Sciences \& Research, Parul University, Limda, Waghodia-391760, Gujarat, India \\ ${ }^{3}$ Department of Biochemistry, NAMO Medical Education and Research Institute, Silvassa, Dadra and Nagar Haveli and Daman and Diu- \\ 396230, India
}

\begin{abstract}
Objectives: This study was conducted to determine the plasma levels of the antioxidants and mineral trace elements in three severity groups of human immunodeficiency virus (HIV) patients compared with non-HIVinfected controls.
\end{abstract}

Methods: The plasma levels of antioxidants (Total antioxidant, albumin, bilirubin, uric acid) and trace elements ( $\mathrm{Mg}, \mathrm{Fe}, \mathrm{Zn}, \mathrm{Mn}, \mathrm{Cu}, \mathrm{Cr}$, Cd and Se) were estimated in spectrophotometrically in controls and patients with CD4 counts $<200 ; 200-499$ and $\geq 500$ cells $/ \mu \mathrm{L}$.

Results: Plasma uric acid and plasma zinc (Zn) were significantly high, while vitamin E and all the micro trace elements (except $\mathrm{Zn}$ ) were significantly lower in HIV-infected patients compared to healthy controls human beings. The higher level of plasma uric acid was observed in those with CD4 counts $<200$ cells $/ \mu \mathrm{L}$. All the trace elements (except Zn) were high levels in HIV subjects with a CD4 count of 200-499 cells/ $\mu \mathrm{L}$ compared to $>500$ cells/ $\mu \mathrm{L}$. Only plasma uric acid and zinc showed significant correlation with CD4 cell count.

Conclusion: Routine assessment of antioxidant/ trace element levels in HIV subjects is recommended. This supplementation is given to strengthen the immune system and reduce the adverse consequences of HIV related oxidative stress and sometimes suggests that assessing antioxidant levels or enzymes activities of patients infected with HIV should be considered during therapy.

Keywords: trace elements; human immunodeficiency virus; antioxidants; CD4 cell; AIDS; oxidative stress

\begin{abstract}
*Corresponding author: Dr. Bhavita Patel, Assistant Professor, Department of Biochemistry, NAMO Medical Education and Research Institute, Silvassa, Dadra and Nagar Haveli and Daman and Diu-396230, India. Email: patel.bhavita2014@gmail.com
\end{abstract}

Received 8 June 2021; Revised 30 August 2021; Accepted 9 September 2021; Published 17 September 2021

Citation: Malapati B, Nadeem SM, Shaker IA, Patel B. Trace elements and antioxidant status in human immunodeficiency virus positive patients. J Med Sci Res. 2021; 9(4):211-216. DOI: http://dx.doi.org/10.17727/JMSR.2021/9-32

Copyright: (C) 2021 Malapati B etal. Published by KIMS Foundation and Research Center. This is an open-access article distributed under the terms of the Creative Commons Attribution License, which permits unrestricted use, distribution, and reproduction in any medium, provided the original author and source are credited. 


\section{Introduction}

Oxidative stress, defined as a disturbance in the balance between the production of reactive oxygen species (free radicals) and antioxidant defenses, is discussed in relation to its possible role in the production of tissue damage in diabetes mellitus. Oxidative stress is a central nervous system to the pathogenesis of HIV, while excessive chronic immune activation from the viral infection has a pro-oxidant effect causes to consumption of antioxidants [1]. In the face of this pathogenesis, reduced dietary intake resulting from chronic liver disease kidney failure hepatitis HIV dementia hypothyroidism, depression, oral sores, loss of livelihood, nutrient malabsorption, and impaired nutrient utilization further compounds the oxidative stress which aggravates the existing immune damage [2]. The research work has shown to that micronutrient supplementation in HIV-positive subjects resulted in lots of benefits including reduced activity of hospitalization [3], increased survival [4], increased weight [5], decreased morbidity/mortality [6], improved birth outcomes and infant immune status [7] and reduced mother to child transmission of HIV virus [8].

This study was carried out to find out whether or not differences exist in the levels of micronutrients/trace elements in HIV patients compared with healthy controls. Another objective was to find out which of these antioxidant micronutrients and trace elements are related to the severity of HIV infection. This may allow identification of the nutritional markers that predict the progression of HIV to AIDS, thus exploring the possibility of dietary supplementation of HIV patients with antioxidant micronutrients or trace elements in the management of these patients.

\section{Materials and methods}

This is a hospital based cross-sectional comparative and observational study carried out at Dr. Kiran C. Patel Medical College and Research Centre, Bharuch, Gujarat, India. Study includes 60 asymptomatic HIV diagnosed patients and aged group of 19-50 years attending the outpatient department (OPD) or inpatient department (IPD) in the Department of Medicine and Surgery from Dec 2019 to May 2021.30 matched healthy HIV-negative health workers were recruited as controls. Ethical approval was obtained from the Ethics Committee at the Dr. Kiran C Patel Medical College Hospital for conducting the study.
Informed consent was obtained from each subject before collection of blood samples. Sample of $5 \mathrm{ml}$ of venous blood was collected from the antecubital vein without venous stasis from each patient into an EDTA tubes. Serum was separated by centrifugation at 3000-4000 rpm for 10-13 minutes and stored in refrigerator at $2-8^{\circ} \mathrm{C}$ till analysis was done. Total antioxidant was estimated using a standardized solution of K2-EDTA complex that reacts with hydrogen peroxide by a Fenton type reaction, leading to the formation of hydroxyl radicals [9]. These reactive oxygen species broken-down then benzoate, resulting in the release of thiobarbituric acid related substances. The rate of inhibition of colored development is proportional to the concentration of anti-oxidative activity. Bilirubin was measured directly by use of quantitative determination of bilirubin. Vitamin E was determined by the method of Baker and Frank [10]. Vitamin E was extracted in xylene and reacted with $\mathrm{x}$-dipyridyl in the presence of ferric chloride to induce a reddish color that is proportional to the concentration of the vitamin $\mathrm{E}$ present in the serum. The optical density was read at $520 \mathrm{~nm}$.

Serum uric acid was determined by the uricase method. Albumin was determined by brilliant cresol green method [11]. The atoms of the elements when aspirated into the atomic absorption spectrophotometer vaporize and absorb light of the same wavelength as that emitted by the element when in the excited state. The CD4 + T lymphocyte cell count was estimated by CyFlow Counter (Partec $\mathrm{GmbH}$, Gorlitz Germany). Manufacturer's procedure for each test was followed accordingly and the findings obtained by the usage of the test kits were taken as the normal ranges.

\section{Statistical analysis}

The results were expressed as mean 8 SD. Comparisons were made using student's $t$ test. Pearson correlation analysis was used to establish possible correlation between antioxidants/ trace elements and CD4 counts.

\section{Results}

Thelevels oftotal antioxidants, albumin, and bilirubin (total and direct) in HIV patients no significantly different compared to controls. However, plasma uric acid was significantly high while the level of 
vitamin E was significantly lower in HIV patients compared with the controls (Table 1). The levels of the trace elements are shown in (Table 2) and all except Zn were significantly lower in HIV patients compared to controls. The mean values of albumin, uric acid, vitamin E, total antioxidant, total bilirubin, and direct bilirubin were not significantly separate in HIV patients with a CD4 count of $<200$ cells $/ \mu \mathrm{L}$ compared with 200-499 cells/ $\mu \mathrm{L}$ (Table 3).

Table 1: Compared to Antioxidants in HIV patients compared with control.

\begin{tabular}{|llll|}
\hline Parameters & HIV (cases60) & Control (30) & P value \\
\hline Albumin g/dl & $5.92 \pm 0.97$ & $4.87 \pm 0.72$ & 0.54 \\
Uric acid mg/dl & $5.61 \pm 1.02$ & $3.92 \pm 1.08$ & 0.01 \\
Vitamin E, mg/l & $9.01 \pm 1.59$ & $9.44 \pm 1.27$ & 0.01 \\
$\begin{array}{l}\text { Total antioxidants, } \\
\mathrm{mM}\end{array}$ & $1.81 \pm 0.52$ & $1.52 \pm 0.28$ & 0.88 \\
$\begin{array}{l}\text { Total bilirubin, } \\
\mathrm{mg} / \mathrm{dl}\end{array}$ & $0.45 \pm 0.18$ & $0.42 \pm 0.12$ & 0.84 \\
$\begin{array}{l}\text { Direct bilirubin, } \\
\mathrm{mg} / \mathrm{dl}\end{array}$ & $0.18 \pm 0.09$ & $0.15 \pm 0.08$ & 0.24 \\
\hline
\end{tabular}

Table 2: Trace elements in HIV patients compared with controls.

\begin{tabular}{|lcc|}
\hline Parameters & HIV (cases 60) & Control (30) \\
\hline $\mathrm{Mg} \mu \mathrm{g} / \mathrm{dl}$ & $45.1 \pm 14.08$ & $57.14 \pm 12.50$ \\
$\mathrm{Fe} \mu \mathrm{g} / \mathrm{dl}$ & $52.10 \pm 15.81$ & $69.12 \pm 16.15$ \\
$\mathrm{Zn} \mu \mathrm{g} / \mathrm{dl}$ & $252.1 \pm 18.02$ & $109.0 \pm 19.11$ \\
$\mathrm{Mn} \mu \mathrm{g} / \mathrm{dl}$ & $45.12 \pm 15.2$ & $63 \pm 9.05$ \\
$\mathrm{Cu} \mu \mathrm{g} / \mathrm{dl}$ & $39.15 \pm 14.12$ & $52.11 \pm 8.90$ \\
$\mathrm{Cr} \mu \mathrm{g} / \mathrm{dl}$ & $3.72 \pm 1.05$ & $5.11 \pm 1.11$ \\
$\mathrm{Cd} \mu \mathrm{g} / \mathrm{dl}$ & $3.9 \pm 1.01$ & $4.07 \pm 1.00$ \\
$\mathrm{Se} \mu \mathrm{g} / \mathrm{dl}$ & $4.01 \pm 1.08$ & $4.91 \pm 1.01$ \\
\hline
\end{tabular}

Note: no difference in trace elements.

The levels of albumin and total antioxidant were significantly higher, while the levels of the direct bilirubin $(p=0.00)$, uric acid $(p=0.04)$ and vitamin $\mathrm{E}(\mathrm{p}=0.00)$ were significantly lower in HIV patients with 500-800 cells/ $\mu \mathrm{L}$ compared with HIV patients having a CD 4 count of $<200$ cells $/ \mu \mathrm{L}$. Plasma albumin and total antioxidant were significantly higher, while uric acid and vitamin E were significantly lower in HIV patients with $>500$ cells $/ \mu \mathrm{L}$ compared with HIV having a CD4 count of 200-499 cells/ $\mu \mathrm{L}$. Mg, Fe, Zn, $\mathrm{Mn}, \mathrm{Cu}, \mathrm{Cr}, \mathrm{Cd}$ and Se were not significantly reduced in HIV patients with CD4! 200 cells/l compared with
HIV patients having CD4 200-499 cells/ $\mu \mathrm{L}$ (Table 4). A similar result was observed in HIV patients with CD $4<200$ cells $/ \mu \mathrm{L}$ compared with HIV patients having $>500$ cells $/ \mu \mathrm{L}$. The levels of $\mathrm{Mg}, \mathrm{Mn}, \mathrm{Cu}, \mathrm{Cr}, \mathrm{Cd}$, and Se were significantly higher in HIV patients with CD4 200-499 cells/ $\mu \mathrm{L}$ compared with HIV patients with CD4 500-800 cells/ $\mu \mathrm{L}$. These two groups of HIV patients, the level of $\mathrm{Zn}$ was significantly lower while Fe did not show any statistically significant difference. Plasma uric acid was negative correlated with CD4 cell counts, while albumin, vitamin E, total antioxidant, total bilirubin and direct bilirubin did not show significant correlation. Only Zinc had a positive relationship with CD4 counts, while remaining trace elements ( $\mathrm{Mg}, \mathrm{Fe}, \mathrm{Mn}, \mathrm{Cu}, \mathrm{Cr}, \mathrm{Cd}$ and $\mathrm{Se}$ ) did not show significant correlation between them.

\section{Discussion}

Plasma levels of micronutrients are assumed to be imperfectindicator of body storage. It has been shown that their deficiencies are common among HIVinfected patients. Micronutrients play an important role in the maintaining immune system function and neutralizing the reactive oxygen intermediates. Micronutrient elements deficiencies in HIV patient individuals exacerbate immunosuppressant, oxidative stress, acceleration of HIV replication and CD4+ T cell depletion [1]. CD4+ T cells are helper T lymphocytes, which are preferentially destroyed by HIV, thus the level of CD4+ T cells is reduced with the severity of HIV infection. This study demonstrated lower levels of trace elements $(\mathrm{Mg}, \mathrm{Fe}, \mathrm{Mn}, \mathrm{Cu}, \mathrm{Cr}$, $\mathrm{Cd}$, and $\mathrm{Se}$ ) and vitamin $\mathrm{E}$, higher levels of uric acid and zinc, and no significant difference in the levels of total antioxidant, albumin and bilirubin in HIV patients when compared with controls, their levels in intra-CD4-group comparison showed consistently lower levels in HIV patients with lower CD4 counts, thereby correlating with severity.

Ames et al. [12] described uric acid as a powerful scavenging antioxidant. Manfred et al. [13] reported a correlation between hyperuricemia and progression of HIV disease as observed in their study. This high plasma uric acid level might be due to rapid cell turnover and muscle wasting as a consequence of oxidative damage to polyunsaturated fatty acid. Uric acid binds ions of copper and iron. Therefore, increased concentration of uric acid gives a falsely elevated concentration of copper and iron, and thus may prevent availability/utilization by tissues. 
Table 3: Antioxidants between different severity groups of HIV patients.

\begin{tabular}{|c|c|c|c|c|c|c|}
\hline \multirow[b]{2}{*}{ Parameters } & \multicolumn{3}{|c|}{ CD4 Count different stages } & \multirow[b]{2}{*}{$t-p(a)$} & \multirow[b]{2}{*}{$t-P(b)$} & \multirow[b]{2}{*}{$t-p(c)$} \\
\hline & $\begin{array}{c}<200 \text { cell } / \mu l \\
\text { (14) }\end{array}$ & $\begin{array}{c}200-499 \text { cell/ } \\
\mu l(26)\end{array}$ & $\begin{array}{c}500-800 \text { cell } / \\
\mu l(20)\end{array}$ & & & \\
\hline Albumin g/dl & $3.10 \pm 0.80$ & $4.1 \pm 1.02$ & $5.15 \pm 1.6$ & $0.36 ; 0.55$ & $6.89 ; 0.0$ & $6.30 ; 00$ \\
\hline Uric acid mg/dl & $3.9 \pm 1.09$ & $3.85 \pm 1.61$ & $4.91 \pm 1.02$ & $0.19 ; 0.76$ & $1.19 ; 0.04$ & $0.19 ; 0.04$ \\
\hline Vit E, mg/l & $8.1 \pm 1.19$ & $8.19 \pm 1.09$ & $7.09 \pm 1.76$ & $0.02 ; 0.79$ & $1.19 ; 0.04$ & $1.96 ; 0.04$ \\
\hline Total antioxidants, $\mathrm{mM}$ & $0.81 \pm 0.29$ & $1.19 \pm 0.79$ & $2.19 \pm 0.19$ & $0.27 ; 0.19$ & $9.10 ; 0.00$ & $3.99 ; 0.00$ \\
\hline Total bilirubin, $\mathrm{mg} / \mathrm{dl}$ & $0.59 \pm 0.19$ & $0.49 \pm 0.19$ & $0.49 \pm 0.19$ & $0.26 \pm 0.79$ & $0.19 ; 0.26$ & $0.99 ; 0.33$ \\
\hline Direct bilirubin, mg/dl & $0.19 \pm 0.19$ & $0.19 \pm 0.10$ & $0.19 \pm 0.08$ & $0.31 ; 0.19$ & $1.13 ; 0.04$ & $0.99 ; 0.33$ \\
\hline
\end{tabular}

Note: T-p(a) means: $<200 \mathrm{Cd} 4$ cells/ $\mu$ compared with 200-499 Cd4 cells/ $\mu \mathrm{l}$; T-P(b) means: $200 \mathrm{~cd} 4$ cells $/ \mu \mathrm{L}$ compared with $>500 \mathrm{Cd} 4$ cells/ $\mu$ l; T-P(c) means: 200-499 cd4 cells / $\mu \mathrm{L}$ compared with >500 Cd4 cells/ $\mu$ l.

Table 4: Trace elements in different severity groups of HIV patients.

\begin{tabular}{|c|c|c|c|c|c|c|}
\hline \multirow[b]{2}{*}{ Parameters } & \multicolumn{3}{|c|}{ CD4 count different stages } & \multirow[b]{2}{*}{$t-p(a)$} & \multirow[b]{2}{*}{$t-P(b)$} & \multirow[b]{2}{*}{$t-p(c)$} \\
\hline & $\begin{array}{c}<200 \mathrm{cell} / \mu \mathrm{l} \\
\text { (14) }\end{array}$ & $\begin{array}{c}200-499 \mathrm{cell} / \mu \mathrm{l} \\
(26)\end{array}$ & $\begin{array}{c}500-800 \mathrm{cell} / \mu \mathrm{l} \\
(20)\end{array}$ & & & \\
\hline $\operatorname{Mg} \mu \mathrm{g} / \mathrm{dl}$ & $38.19 \pm 19.12$ & $42.41 \pm 13.64$ & $38.20 \pm 11.15$ & $0.18 ; 0.14$ & $1.11 ; 0.11$ & $1.84 ; 0.01$ \\
\hline $\mathrm{Fe} \mu \mathrm{g} / \mathrm{dl}$ & $41.11 \pm 18.18$ & $48.11 \pm 12.14$ & $35.0 \pm 13.34$ & $0.61 ; 0.32$ & $0.21 ; 0.17$ & $0.89 ; 0.05$ \\
\hline $\mathrm{Zn} \mu \mathrm{g} / \mathrm{dl}$ & $119.1 \pm 46.2$ & $42.21 \pm 12.11$ & $512.0 \pm 18.11$ & $0.80 ; 0.31$ & $0.51 ; 0.4$ & $8 ; 1 ; 0.00$ \\
\hline $\mathrm{Mn} \mu \mathrm{g} / \mathrm{dl}$ & $51.11 \pm 18.19$ & $42.11 \pm 14.1$ & $38.18 \pm 11.31$ & $0.57 ; 0.42$ & $0.92 ; 0.11$ & $1.9 ; 0.01$ \\
\hline $\mathrm{Cu} \mu \mathrm{g} / \mathrm{dl}$ & $38.19 \pm 19.19$ & $49.01 \pm 10.4$ & $29.11 \pm 14.11$ & $047 ; 0.48$ & $0.92 ; 0.17$ & $2.09 ; 0.00$ \\
\hline $\mathrm{Cr} \mu \mathrm{g} / \mathrm{dl}$ & $3.9 \pm 1.19$ & $4.11 \pm 1.09$ & $3.9 \pm 1.1$ & $0.76 ; 0.40$ & $0.09 ; 0.31$ & $1.7 ; 0.001$ \\
\hline $\mathrm{Cd} \mu \mathrm{g} / \mathrm{dl}$ & $3.1 \pm 1.82$ & $4.82 \pm 1.21$ & $3.8 \pm 1.8$ & $0.68 ; 0.42$ & $1.09 ; 0.32$ & $2.8 ; 0.01$ \\
\hline Se $\mu \mathrm{g} / \mathrm{dl}$ & $4.18 \pm 1.19$ & $4.2 \pm 1.1$ & $3.7 \pm 1.4$ & $0.42 ; 0.58$ & $1.82 ; 0.16$ & $2.7 ; 0.01$ \\
\hline
\end{tabular}

Note: T-p(A) means :<200 Cd4 cells/ $\mu$ compared with 200-499 Cd4 cells/ $\mu \mathrm{l}$; T-P(b) means: $200 \mathrm{Cd} 4$ cells $/ \mu \mathrm{L}$ compared with $>500 \mathrm{Cd} 4$ cells/ $\mu$ l; T-PC means: 200-499 cd4 cells $/ \mu \mathrm{L}$ compared with $>500 \mathrm{Cd} 4$ cells $/ \mu \mathrm{l}$.

Vitamin E, which was found to be lower in HIV patients compared with controls, is a result of its increased utilization in quenching free radicals and thereby prevents peroxidation of polyunsaturated fatty acids. Poor dietary intake, poor absorption and diarrhea in HIV subjects contribute to the reduced level of vitamin E in HIV subjects. It is also possible that the recycling mechanism of biologically active vitamin E through ascorbate is impaired in HIV patients. Coutsoudis et al. [14] reported low vitamin $\mathrm{E}$, along with vitamin $\mathrm{A}$ and carotene as part of biochemical manifestations in HIV/AIDS patients. In this study, progressive reduction in vitamin $\mathrm{E}$ level in HIV patients was observed when the three severity groups were compared. Studies had shown that double intake of vitamin $\mathrm{E}$ decreased the risk of progression to AIDS [15]. However, there was no correlation between vitamin $\mathrm{E}$ and CD4 count in our study. Therefore, vitamin E level may be used as a marker of severity in HIV infection.

When HIV patients and controls were compared, albumin, total antioxidant, and bilirubin levels did not show any statistically significant difference. This may suggest minimal oxidative injury from oxidative stress, fairly good nutritional status, and healthy 
hepatic status. According to Lichterfeld et al. [16], liver function tests become abnormal in $60-70 \%$ of AIDS patients and bilirubin usually remains normal. However, a high bilirubin commonly arises from bacteria sepsis, chronic active hepatitis and micro nodular cirrhosis. Therefore, it is not surprising that HIV patients with CD $4<200$ cells/ $\mu$ lis the only group whose bilirubin was significantly raised when compared with those with $>500$ cells $/ \mu \mathrm{L}$. A low albumin level carries a poor prognosis but is a strong independent predictor of mortality [17]. Albumin is equally a determinant of nutritional status, hepatic function and renal protein wasting [18], comparison of the three severity groups showed consistently decreasing levels of albumin and total antioxidant and consistently increasing levels of uric acid and vitamin $\mathrm{E}$ in those with low $\mathrm{CD} 4$ counts. The reason for the higher level of vitamin $\mathrm{E}$ in HIV individuals with lower CD4 count among the severity groups remains elusive. However, unregulated vitamin supplementations may be responsible. Lower levels of trace elements were observed in HIV patients when compared with controls, but statistically significant higher levels of trace elements were obtained in patients with a CD4 count of 200-499 cells $/ \mu \mathrm{L}$ compared with those with $>500$ cells $/ \mu \mathrm{L}$. Other severity groups did not show any statistically significant differences. This is again difficult to explain but overzealous supplementation may also be accountable.

In this study, the level of zinc was statistically significantly higher in HIV-infected subjects compared with the controls. Arinola et al. [17] found lower levels of some trace elements (such as $\mathrm{Cu}$, $\mathrm{Mg}, \mathrm{Fe}, \mathrm{Zn}, \mathrm{Cd}$, Se and $\mathrm{Cr}$ ) compared to controls, and also observed similar levels of zinc in asymptomatic HIV-infected patients compared with controls. The contrast between their result and the result of the present study may be due to subject selection. Arinola et al. [17] recruited asymptomatic HIV subjects whose CD4 count or immune status may still be close to normal. It is therefore possible that changes in zinc level occur when the immune system or CD4 count is falling, and thus may be a useful indicator of advanced HIV infection. Plasma zinc may be normal or high in asymptomatic HIVinfected patients, and a steady decline is expected as immunodeficiency. The level of zinc is increased in HIV-infected patients compared with controls may also be part of an unregimented measure to manage this disease in this environment. Most of the infected individuals accept all forms of unorthodox treatment, part of which usually includes the use of herbs and dietary advice. Some of these may be a source of zinc to these patients. High level of plasma zinc in these patients could be beneficial since zinc could be both an inhibitor of reverse transcriptase and an activator of the 'tat' protein. Caselli and Biochi [19] demonstrated an increase in CD4 cells and reduced progression of disease when zinc sulphate supplementation was given to AIDS patients with low zinc level. Most of the documented articles show that, trace elements studied are usually linked directly or indirectly with several metalloenzymes having antioxidant activities. The HIV-infected subjects may be due to consumption as a result of oxidative stress. Apartfrom dietary supplementation, the involvement of cytokines in regulating the levels of certain trace elements should be considered. Cytokines play an important role in controlling the homeostasis of the immune system, complement system and HIV infection results in deregulation of the cytokine profile. During the medication of HIV infection, secretion of proinflammatory cytokines (IL-1, IL-6 and IL-8) is increased [20]. The Production of proinflammatory cytokine is known to lower the plasma levels of $\mathrm{Fe}+$ and $\mathrm{Zn}$ +but raises that of $\mathrm{Cu}+$ [21]. Our studies showed a reduced level of $\mathrm{Cu}$, which could be due to reduction in the synthesis of ceruloplasmin by liver. Reduced synthetic function of the liver and negative influence of proinflammatory cytokines on albumin synthesis could also explain the low level of albumin in HIV patients. Albumin is a negative acute-phase reactant that is reduced during infection and inflammation, thus its importance in being a predictor of mortality. This explains why a lower CD4 count is associated with reduced albumin concentration. It is plausible that the results obtained in this study could be due to dietary deficiency of trace elements or cytokinedriven inflammatory responses.

\section{Conclusion}

This study supports the fact that oxidative stress culminates into deficiency of antioxidants/ some micronutrients in HIV-infected patients with consequent tissue damage, and demonstrates that uric acid and zinc showed a clear correlation with the severity of HIV. Routine assessment of antioxidant/ trace element levels in HIV subjects is recommended, so that appropriate supplementation 
with antioxidants/ trace elements is advised for HIV patients with demonstrably low levels in order to limit oxidative stress. Some more studies are needed to better understand and define the roles of trace mineral and vitamin deficiencies and micronutrient supplementation in the management and treatment of HIV-infected patients.

\section{Acknowledgments}

We extend our gratitude to the staff of the Department of Biochemistry for providing the support and guidance to complete this project. We are highly grateful to the patients who volunteered to be a part of this study.

\section{Conflicts of interests}

Authors declare no conflicts of interests.

\section{References}

[1] Fuchs J, Ochsendorf F, Schofer H. Oxidative imbalance in HIV infected patients. Med Hypotheses. 1991; 36:60-64.

[2] Munyazesa E, Emile I, Mutimura E, Hoover DR, Shi Q, et al. Assessment of haematological parameters in HIV-infected and uninfected Rwandan women: A cross-sectional study. BMJ Open. 2012; 2(6): 0001600.

[3] Semba RD, Tang AM. Micronutrients and pathogenesis of human immunodeficiency virus infection. Br J Nutr. 1999; 81(3):181-189.

[4] Jiamton S, Pepin J, Suttent R, Filteau S, Mahakkanukrauh $\mathrm{B}$, et al. A randomized trial of the impact of multiple micronutrient supplementation on mortality among HIV infected individuals living in Bangkok. AIDS. 2003; 17(17):2461-2469.

[5] Villamor G, Mzanga G, Spiegelman D, Antelman G, Hunter DJ, et al. Effect of multivitamin and vitamin A supplements on weight gain during pregnancy among HIV-1 infected women. Am J Clin Nutr. 2002; 76(5):1082-1090.

[6] World Health Organization. Global situation of the HIV/AIDS pandemic. Bull World Health Organ. 2003; 78:417-447.

[7] Fawzi W, Msamanga G, Hunter D. Randomized trial of vitamin supplements in relation to transmission of HIV-1 through breastfeeding and early child mortality. AIDS. 2002; 16(14):1935-1944.

[8] Fawzi W. Micronutrients and human immunodeficiency virus type 1 disease progression among adults and children. Clin Infect Dis. 2003; 37(suppl 2):S112-S116.

[9] Grey CE, Adlercreutz P. Evaluation of multiple oxidation products for monitoring effects of antioxidants in Fenton oxidation of 2-deoxyguanosine. J Agric Food Chem. 2006; 54(6):2350-2358.

[10] Baker H, Frank O. Determination of vitamin E; in Baker H, Frank $\mathrm{O}$ (eds): Clinical Vitaminology: Methods and Interpretation. New York, Wiley, 1968, pp.172-176.

[11] Spencer K, Price CR. The determination of serum albumin using bromocresol green. Ann Clin Biochem. 1977; 14:105.

[12] Ames BN, Shigenaga MK, Hagen TM. Oxidants, antioxidants and the degenerative diseases of ageing. Proc Natl Acad Sci USA. 1993; 90(17):7915-7922.
[13] Manfredi R, Mashoianni A, Olgia V, Chiodo F. Hyperuricaemia and progression of HIV disease. J Acquir Immune Defic Syndr Hum Retrovirol. 1996; 12(3):318-319.

[14] Coutsoudis A, Bobat R, Coovadia HM. The effect of vitamin A supplementation on the morbidity of children born to HIV infected women. Am J Public Health. 1995; 85(8pt1):76-80.

[15] Tang MA, Graham NH, Semba R, Saah AJ. Association between serum vitamin $A$ and $E$ levels and HIV-1 disease progression. AIDS. 1997; 11(5):613-620.

[16] Lichterfeld M, Haas S, Fischer HP, Voigt E, Rockstroh JK, et al. Liver histopathology in human immunodeficiency virushepatitis $\mathrm{C}$ virus co-infected patients with fatal liver disease. J Gastroenterol Hepatol. 2005; 20(5):739-745.

[17] Arinola OG, Adedapo KS, Kehinde AO, Olaniyi JA, Akiibinu MO. Acute phase proteins and trace elements in asymptomatic human immunodeficiency virus infection in Nigerians. Afr J Med Sci. 2004; 33(4):317-322.

[18] Feldman JG, Gange ST, Bacchet P, Chen M, Young M, et al. Serum albumin is a powerful predictor of survival among HIV-1 infected women. J AIDS. 2003; 33(1):66-73.

[19] Caselli M, Biochi R: Serum zinc levels in patient with acquired immunodeficiency syndrome. Press Med. 1996; 15(37):1877-1886.

[20] Kedzierska K, Crowe SM. Cytokines and HIV: Interactions and clinical implications. Antivir Chem Chemother. 2001; 12(3):133-150.

[21] Klaus-Helge I, Lothar R. Zinc-altered immune function. J Nutr. 2003; 133(5 Suppl 1):14525-14565. 